\title{
Sphagnum Peat in the Growing Medium and Nitrogen Application Influence Asparagus Growth
}

\author{
Luther Waters, Jr. ${ }^{1}$, Bonnie L. Blanchette ${ }^{2}$, Rhoda L. Burrows ${ }^{3}$, and \\ David Bedford 4 \\ Department of Horticultural Science and Landscape Architecture, \\ University of Minnesota, St. Paul, MN 55108
}

Additional index words. Asparagus officinalis, nutrition (plant), soil amendments, sand, $\mathrm{pH}$, root growth, seedling

\begin{abstract}
High levels of sphagnum peat in the growing medium promoted growth of asparagus (Asparagus officinalis L. cv. Viking $2 \mathrm{~K}$ ) in a greenhouse study. Application of $\mathrm{NH}_{4} \mathrm{NO}_{3}>1 \mathrm{~g} /$ pot $\left(84 \mathrm{~kg} \cdot \mathrm{ha}^{-1}\right.$ equivalent $)$ was detrimental to root growth. High $\mathrm{N}$ rates and high organic matter levels decreased fibrous root development. Shoot dry weight was highly correlated with fleshy root number, root dry weight, and shoot vigor.
\end{abstract}

Sandy loam soil is generally recommended for growing commercial asparagus, although large areas of peat soils are devoted to asparagus production in the San Joaquin Delta of California. Adequate aeration and good drainage are necessary for development of the underground portion of the plant that consists of buds, rhizomes, and fleshy and fibrous roots. The effect of organic matter levels on root and shoot growth of asparagus has not been reported.

Nitrogen, the nutrient most often limiting plant growth, can significantly influence both asparagus crown development and subsequent yields. Recommendations for crown production range from $\mathrm{N}$ at 22.4 to 44.8 $\mathrm{kg} \cdot \mathrm{ha}^{-1}$ (Sanders et al., 1952) to 84 to 112 $\mathrm{kg} \cdot \mathrm{ha}^{-1}$ (Curwen, 1988). Fisher and Benson (1983, 1984) found that $\mathrm{N}$ levels of up to $150 \mathrm{mg} \cdot$ liter $^{-1}$ increased shoot and root numbers and weights and shoot : root (SR) ratios of seedling asparagus. A further increase to $200 \mathrm{mg} \cdot \mathrm{liter}^{-1}$ led to further increases in shoot number and weight, but not in root weight. Adler et al. (1981) found an increase in shoot weight, but not shoot number, with $\mathrm{N}$ levels to $200 \mathrm{mg} \cdot$ liter $^{-1}$ accord-

Received for publication 16 Jan. 1990. Paper no. 17,810 of the Scientific Journal Series, Univ. of Minnesota Agrtcultural Experiment Station. The cost of publishing this paper was defrayed in part by the payment of page charges. Under postal regulations, this paper therefore must be hereby marked advertisement solely to indicate this fact.

${ }^{1}$ Professor.

${ }^{2}$ Associate Scientist.

Research Fellow.

${ }^{4}$ Assistant Scientist. ingly, $S: R$ weight ratios, but not $S: R$ number ratios, were increased. Studies with many other crops have shown a greater partitioning to roots at low $\mathrm{N}$ levels (Brouwer, 1962). Brasher (1959) found that neither spear yield nor $\mathrm{N}$ content of the fern increased with levels $>44.8 \mathrm{~kg} \cdot \mathrm{ha}^{-1}$. Cline (1969) was able to demonstrate increased yields with $89.6 \mathrm{~kg}$ $\mathrm{N} / \mathrm{ha}$, but not with $179 \mathrm{~kg}$. Reductions in yield have been reported when $\mathrm{N}$ levels exceeded $112 \mathrm{~kg} \cdot \mathrm{ha}^{-1}$ (Mullins and Swingle. 1979).

Our study was initiated to investigate whether soils high in organic matter $(100 \%$ peat) represent a productive asparagus growing medium and whether application of supplemental $\mathrm{N}$ to those soils is beneficial. We, therefore, determined the response of young asparagus transplants to various levels of peat and $\mathrm{N}$ in the growing medium.

'Viking $2 \mathrm{~K}$ ' asparagus seeds were soaked at $16-27 \mathrm{C}$ for 12 days in water that was changed daily. The seeds were then planted in cell-packs containing a sterile medium composed of 1 sphagnum peat : 1 vermiculite $(\mathrm{v} / \mathrm{v})$. No fertilizer was applied. After 90 days, plants bearing two to four shoots were

Table 1. Medium $\mathrm{pH}$ values.

\begin{tabular}{ccc}
\hline \multicolumn{2}{c}{ Mcdium proportion } & \\
\cline { 1 - 2 } Pcat & Sand & $\mathrm{pH}$ \\
\hline 0 & 1 & 8.30 \\
1 & 3 & 7.63 \\
1 & 1 & 6.82 \\
3 & 1 & 6.13 \\
1 & 0 & 4.24 \\
\hline
\end{tabular}




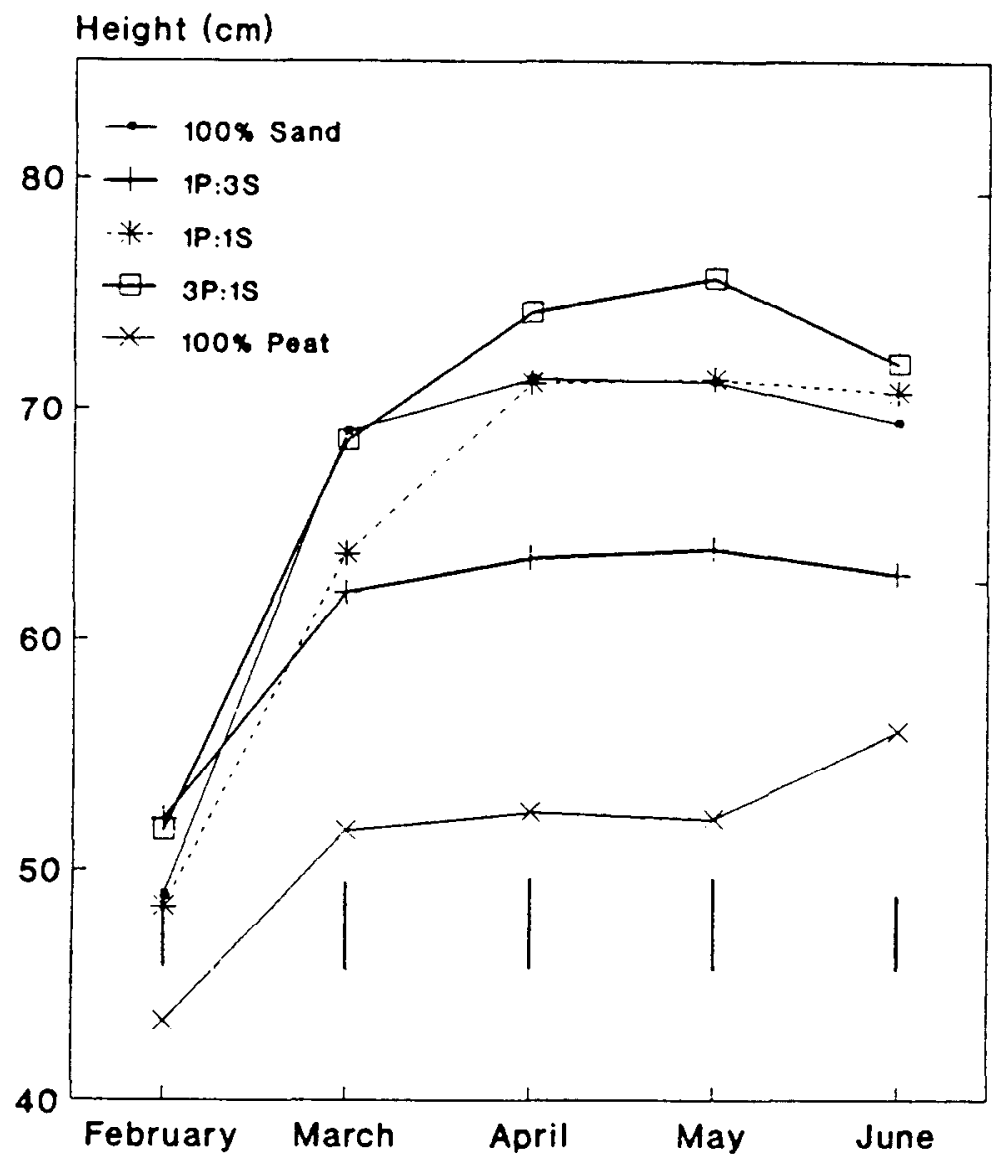

Fig. 1. Influence of peat in the growing medium on asparagus shoot height during 4 months with supplemental $\mathrm{N}$ at $1 \mathrm{~g} / \mathrm{pot}$. Bars indicate SE of treatment means.

Table 2. Response of seedling asparagus to organic matter in growing media. ${ }^{\mathrm{z}}$

\begin{tabular}{|c|c|c|c|c|c|c|c|}
\hline \multirow{2}{*}{$\begin{array}{l}\text { Peat : sand } \\
\text { ratio }\end{array}$} & \multirow[b]{2}{*}{ Bud no. } & \multirow{2}{*}{$\begin{array}{l}\text { No. } \\
\text { fleshy } \\
\text { roots }\end{array}$} & \multicolumn{2}{|c|}{ Drv wi (g) } & \multirow{2}{*}{$\begin{array}{c}\text { Final } \\
\text { vigor } \\
\text { (ratingy) }\end{array}$} & \multirow{2}{*}{$\begin{array}{l}\text { Final ht } \\
(\mathrm{cm})\end{array}$} & \multirow{2}{*}{$\begin{array}{c}\text { Shoot : root } \\
\text { ratio }\end{array}$} \\
\hline & & & Root & Shoot & & & \\
\hline $0 P: 1 S$ & 10.2 & $35 \mathrm{a}$ & $16.8 b$ & $3.0 \mathrm{a}$ & 1.8 & 61.2 & $0.17 \mathrm{a}$ \\
\hline I P:3S & 11.1 & $42 \mathrm{~b}$ & $19.1 \mathrm{bc}$ & $3.8 \mathrm{bc}$ & 2.3 & 59.2 & 0.19 a \\
\hline IP:IS & 10.3 & $39 a b$ & $18.2 \mathrm{~b}$ & $4.4 c$ & 2.6 & 64.1 & $0.26 \mathrm{~b}$ \\
\hline $3 P: 1 S$ & 12.4 & $48 \mathrm{c}$ & $21.8 \mathrm{c}$ & $6.0 \mathrm{~d}$ & 2.9 & 70.3 & 0.29 bc \\
\hline $1 P: 0 S$ & 10.6 & 43 bc & $11.1 \mathrm{a}$ & $3.4 a b$ & 2.7 & 52.3 & $0.31 \mathrm{c}$ \\
\hline LSO & NS & 6.4 & 3.1 & 0.72 & 0.4 & 4.7 & 0.048 \\
\hline
\end{tabular}

${ }^{\mathrm{z}}$ Separation within columns by Fisher's protected LSD $=0.05$.

${ }^{\mathrm{y}} 1=$ Low vigor, $5=$ high vigor.

Table 3. Response of seedline asparagus to nitrogen fertilization. ${ }^{\mathrm{z}}$

\begin{tabular}{|c|c|c|c|c|c|c|c|}
\hline \multirow{2}{*}{$\begin{array}{l}\text { N level } \\
\text { (g/pot) }\end{array}$} & \multirow[b]{2}{*}{ Bud no. } & \multirow{2}{*}{$\begin{array}{l}\text { No. } \\
\text { fleshy } \\
\text { roots }\end{array}$} & \multicolumn{2}{|c|}{ Dry wt $(\mathrm{g})$} & \multirow{2}{*}{$\begin{array}{c}\text { Final } \\
\text { vigor } \\
\text { (rating') }\end{array}$} & \multirow{2}{*}{$\begin{array}{c}\text { Final ht } \\
\text { (cm) }\end{array}$} & \multirow{2}{*}{$\begin{array}{c}\text { Shoot : root } \\
\text { ratio }\end{array}$} \\
\hline & & & Root & Shoot & & & \\
\hline 0 & $9.5 \mathrm{a}$ & 31 d & $12.7 \mathrm{a}$ & $1.9 \mathrm{a}$ & 1.5 & 54.4 & $0.15 \mathrm{a}$ \\
\hline 1 & $12.1 \mathrm{~b}$ & $49 \mathrm{~b}$ & $21.4 \mathrm{c}$ & $5.2 \mathrm{~b}$ & 2.8 & 66.2 & $0.26 \mathrm{~b}$ \\
\hline 2 & $11.2 \mathrm{~b}$ & $44 b$ & $18.1 \mathrm{~b}$ & $5.3 \mathrm{~b}$ & 3.1 & 63.5 & $0.33 c$ \\
\hline LSD & 1.6 & 4.9 & 2.4 & 0.55 & 0.3 & 3.7 & 0.037 \\
\hline
\end{tabular}

${ }^{\mathrm{z}}$ Separation within columns by Fisher's protected LSD $=0.05$.

${ }^{\mathrm{y}} 1$ = Low vigor; $5=$ high vigor.

transplanted into 10.9-liter pots containing one of five media: 1) riverbed sand (Carver County, Minn.), 2) 1 sphagnum peat (Western Peat Moss, Vancouver, B.C.) : 3 sand (1P:3S), 3) 1 peat : 1 sand (1P:1S), 4) 3 peat : 1 sand (3P:1S), 5) peat. The $\mathrm{pH}$ of each medium was taken at the time of transplanting (Table 1). The values found with these mixes correspond roughly to soil $\mathrm{pH}$ levels that have been observed in cultivated soil types.

The study was designed as a randomized complete-block factorial experiment with the five peat : sand mixes, three $\mathrm{N}$ levels, and five replications with two observations (plants) per experimental unit. The three $\mathrm{N}$ levels, 0 , 1 , or $2 \mathrm{~g} / \mathrm{pot}$ (equivalent to $0,84,168$ $\left.\mathrm{kg} \cdot \mathrm{ha}^{-1}\right)$, were applied as split applications of $\mathrm{NH}_{4} \mathrm{NO}_{3}(34 \% \mathrm{~N}) 1$ and 3 months after transplanting. Superphosphate $(8.7 \% \mathrm{P})$ and $\mathrm{KCl}(60 \% \mathrm{~K})$ were applied 1 month after transplanting at rates of 1 and $1.5 \mathrm{~g} /$ pot, respectively. Dry applications of all fertilizers were made using a dibble to place the treatment $\approx 2.5 \mathrm{~cm}$ below the soil surface. Micronutrients were applied 5 weeks after transplanting using Soluble Trace Element Mixture (STEM; W.R. Grace \& Co., Fogelsville, Pa.) dissolved in water at a rate of $1 \mathrm{~g}$ STEM/liter. The asparagus transplants were grown under natural light in the greenhouse at 24 to $29 \mathrm{C}$ (day)/16C (night) and watered by treatment as needed.

Heights of the tallest shoots and ratings of shoot vigor (based on a scale of 1 to 5 , with 5 as most vigorous) were recorded monthly. The study was terminated 5 months after transplanting, before the containers restricted root growth. The root systems were washed sufficiently for visual observation, and the number of healthy buds and fleshy roots recorded. Fibrous root growth was scored on a scale of 1 to 5 , with 5 as healthiest and most highly developed. Dry weights of the root and shoot were recorded and an $S: R$ ratio calculated for each plant.

Growth of asparagus seedlings was generally favored by increased levels of peat in the growing medium, but only up to $3 \mathrm{P}: 1 \mathrm{~S}$. (Table 2). Plants in the 3P:1S mixture had significantly better shoot and fleshy root development than in media with less peat, and although differences were not significant, plants in the 3P:1S medium had the most buds. Shoots on plants in the 3P: 1S medium averaged $15 \%$ taller, $61 \%$ more vigorous, and twice as heavy (dry weight) as plants grown in $100 \%$ sand (Table 2 ).

Applications of $1 \mathrm{~g} \mathrm{~N} /$ pot increased bud number, fleshy root number, and shoot height compared with $0 \mathrm{~N}$ (Table 3). Except for root dry weight and $S: R$ ratio, differences between 1 and $2 \mathrm{~g} \mathrm{~N} /$ pot were not significant. However, plants grown at the lower level of $\mathrm{N}$ were the most vigorous. These results are in agreement with the studies cited previously.

In a perennial plant, such as asparagus, it is desirable to have a high $S: R$ ratio soon after harvest to maximize the photosynthetic area. Later in the season, however, applications of high levels of $\mathrm{N}$ could significantly reduce growth of the fleshy roots (Brouwer, 1962; Fisher and Benson, 1983, 1984) and possibly reduce yield in the following year due to decreased carbohydrate reserves (Mullins and Swingle, 1979; Pitman and Sanders, 1985). In this study, the $S: R$ ratio increased with increasing levels of peat and of $\mathrm{N}$ (Tables 2 and 3). Although both shoot and root dry weights were increased by these treatments, the shoot response was greater. Extensive shoot growth, as reflected by increases in plant height and ratings for fern vigor (Tables 2 and 3). resulted from increases in $\mathrm{N}$ and peat. These results agree with those of Yanada and Karimata (1969), who found that plants grown on sandy soil had lower $\mathrm{S}: \mathrm{R}$ ratios compared to those grown on loamy soil. 


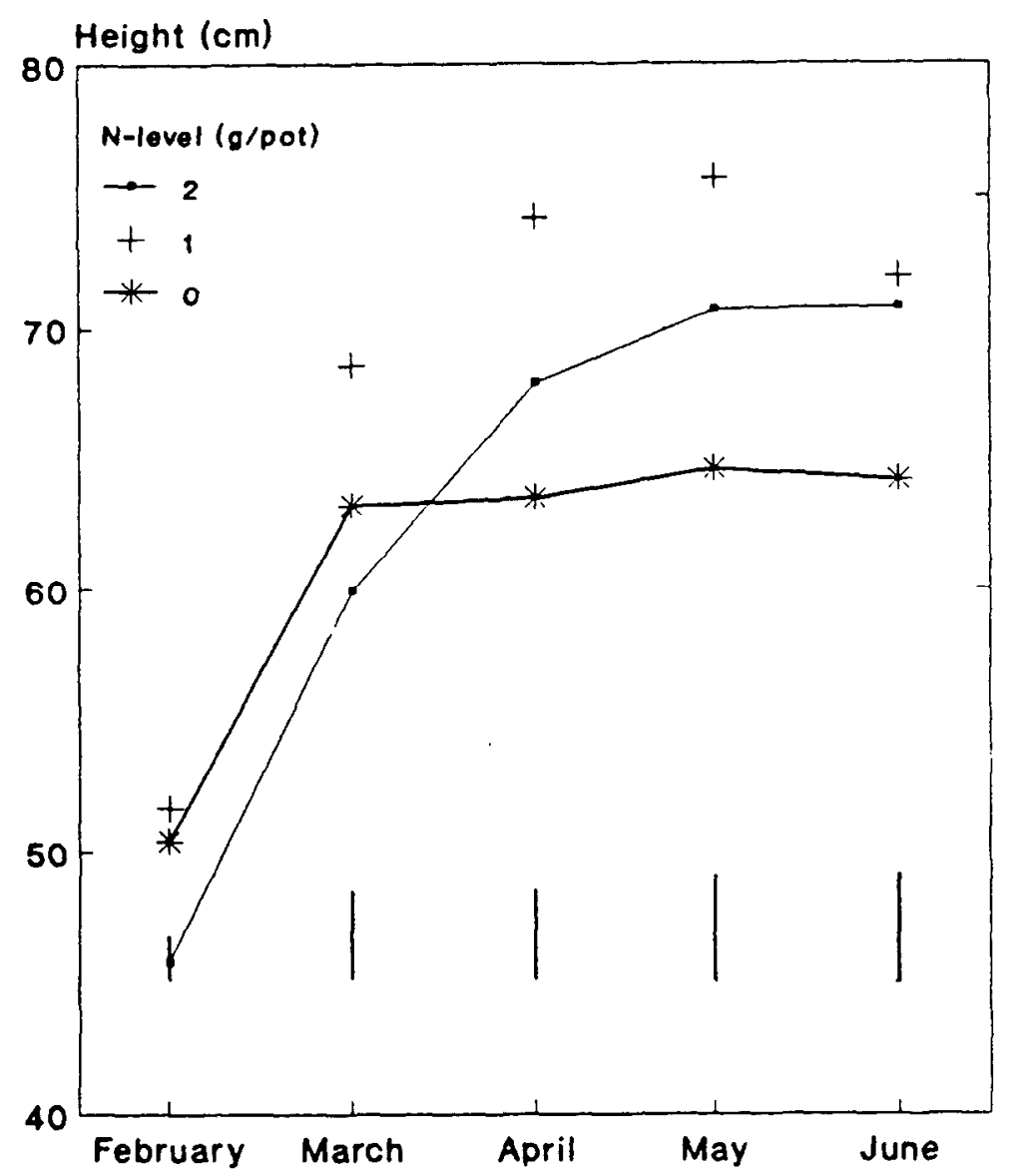

Fig. 2. Influence of $\mathrm{N}$ level on asparagus shoot height during 4 months in a 3 peat : 1 sand medium. Bars indicate SE of treatment means.

Table 4. Effect of $\mathrm{N}$ level and percentage of peat in growing media on fibrous root growth.

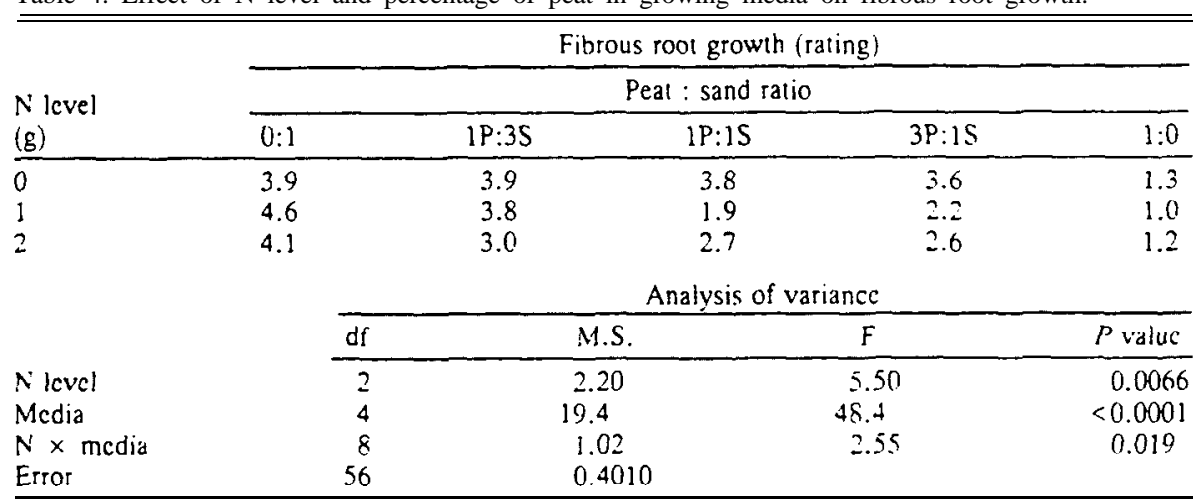

Table 5. Conclarions $(r \text { values })^{\mathrm{z}}$ of seedling asparagus components.

\begin{tabular}{|c|c|c|c|c|c|c|c|}
\hline \multirow[b]{2}{*}{ Component } & \multirow{2}{*}{$\begin{array}{l}\text { Buds } \\
\text { (no.) }\end{array}$} & \multicolumn{3}{|c|}{ Roots } & \multicolumn{3}{|c|}{ Shoots } \\
\hline & & Fleshy & Fibrous & Dry wt & Dry w & Vigor & $\mathrm{Hi}$ \\
\hline Bud number & 1.00 & & & & & & \\
\hline Flcshy rool number & 0.57 & 1.00 & & & & & \\
\hline Fibrous rool number & 0.14 & NS & 1.00 & & & & \\
\hline Root dry weight & 0.51 & 0.73 & 0.31 & 1.00 & & & \\
\hline Shoot dry weight & 0.40 & 0.71 & NS & 0.70 & 1.00 & & \\
\hline Shool vigor & 0.30 & 0.62 & -0.34 & 0.44 & 0.77 & 1.00 & \\
\hline Shoot hcight & 0.31 & 0.28 & 0.20 & 0.56 & 0.59 & 0.35 & 1.00 \\
\hline
\end{tabular}

${ }^{\mathrm{z}}$ Correlations not significant (NS) or significant at $P<0.001$.

A highly significant interaction between $\mathrm{N}$ and peat level was observed for fibrous root growth (Table 4). In general, $\mathrm{N}$ at $1 \mathrm{~g} / \mathrm{pot}$ suppressed fibrous root growth in the 1P:1S and 3P:1S media. Fibrous root growth was not inhibited by this level of $\mathrm{N}$ in media low in organic matter, possibly due to rapid leaching of the $\mathrm{N}$. In fact, $1 \mathrm{~g} \mathrm{~N}$ significantly increased fibrous root growth on plants grown in $100 \%$ sand. Inhibition of fibrous roots was observed in all media except $100 \%$ sand and $100 \%$ peat when $2 \mathrm{~g} \mathrm{~N} /$ pot was applied. The poor fibrous root growth in $100 \%$ peat was not necessarily due to toxic levels of $\mathrm{N}$ since growth was also suppressed in the absence of $\mathrm{N}$.

The shoot response to $\mathrm{N}$ and peat levels paralleled that of the fleshy roots (Tables 2 and 3). Shoot growth at the optimal level of $\mathrm{N}(1 \mathrm{~g} / \mathrm{pot})$ and best growing medium (3P:1S) are shown in Figs. 1 and 2, respectively. Growth curves for other treatments were similar (data not shown). Although, generally, treatments high in organic matter were best, the use of $100 \%$ peat was a dramatically inferior treatment throughout the experiment. Likewise, $1 \mathrm{~g} \mathrm{~N} /$ pot was clearly superior to 0 or $2 \mathrm{~g} \mathrm{~N} /$ pot throughout the experiment.

Highly significant correlations between the fleshy root system and shoot dry weight and fern vigor (Table 5) may be due to both plant parts being carbohydrate sinks. The fibrous roots did not respond in a similar manner as the fleshy root or shoot systems, as reflected by the low correlations. For instance, addition of $\mathrm{N}$ increased fern growth and the number of fleshy roots, but decreased fibrous root growth (Table 4).

The results of this study give an indication of plant responses that might be obtained in establishing an asparagus planting in the field. Separation of the impact of the organic matter levels from that of the $\mathrm{pH}$ on plant growth is not possible. Separate studies are needed to make these determinations possible and to give growers recommendations for manag$\mathrm{mg}$ soil for asparagus production. However, based on these studies. soils high in peat may be a better growing environment than sand soils. In addition, $\mathrm{N}$ applications $>84 \mathrm{~kg} \cdot \mathrm{ha}^{-1}$ may not be of value and could be counterproductive late in the fern production period.

\section{Literature Cited}

Adler. P.R., R.J. Dufault, and L. Waters, Jr. 1984. lnflucnce of nitrogen. phosphorus, and porassium on asparagus transplant quality. HortScience 19(4):565-566.

Brasher, E.P. 1959. Establishing fertilizer requirements for asparagus through tissue analysis. Proc. Amer. Soc. Hort. Sci. 73:334-338.

Brouwer, R. 1961. Nutritive influences on the dis tribution of dry matter in the plant. Netherlands J. Agr. Sci. 10(5):399-408.

Cline, R.A. 1969. The effect of irrigation, organic amendments, time and rate of nitrogen applications on asparagus yields and tissue nutrient composition. Rpt. Hort. Res. Inst. Ont. 1968. 1969:10-16.

Convert, D. (ed.). 1985. Commercial vegetablc production in Wisconsin. Univ. of Wisconsin Coop. Ext. Bul. A3422.

Fisher. K.J. and B.L. Benson. 1983. Effects of nitrogen and phosphorus nutrition on the growth of asparagus seedlings. Scientia Hort. 21:105112.

Fisher, K.J. and B.L. Benson. 1984. The effect of nitrogen, volume of media, plant density and module shape on the growth of asparagus seedlings. Scientia Hort. 24:45-51.

Mullins, C.A. and H.D. Swingle. 1979. The effect of fcrtilization levels on asparagus production. Tenn. Farm \& Home Sci. 112:33-34.

Pitman, B. and D.C. Sanders. 1985. Effect of N 
fertilization on pre-commercial asparagus growth and development, p. 330-332. In: E.C. Loughted and H. Tiessen (eds.). Eucarpia Veg. Section: Proc. 6th Intl. Asparagus Symp. Guelph.
Ont., Canada.

Sanders, D., E. Estes, and T.J. Monaco. 1982.

Asparagus crown production. North Carolina

Agr. Ext. Serv. Hort. Info. Lflt. 26.
Yanada, K. and A. Karimata. 1969. Ecological studies on the root system of vegetable crops in the different soils. J. Agr. Sci. (Tokyo) 14:4970 . 